\title{
FAKTOR FAKTOR YANG MEMPENGARUHI PERSEPSI MAHASISWA TENTANG MATA KULIAH KEWIRAUSAHAAN
}

\author{
Abdul Mirad,Nurpeni dan Elly Nielwaty \\ Universitas Lancang Kuning \\ Email: abdulmirad@unilak.ac.id
}

\begin{abstract}
Penelitian ini dilaksanakan Dengan jangka waktu Penelitian 3 (tiga) Bulan. Dimana populasi dan sampelnya berjumlah 42 orang terdiri dari mahasiswa semesterVII kelas pagi Fia Unilak.Teknik pengambilan sampel menggunakan teknik sensus. Jenis data yang diambil dalam penelitian ini meliputi data, pengalaman masa lalu,keyakinan,dan pengalaman orang lain Konsep teori yang digunakan menggunakan konsep Vincent Gaspers. Analisis data dalam penelitian ini menggunakan analisis deskriptif kualitatif. Penelitian ini didanai oleh Fakultas Ilmu Administrasi dengan dana serjumlah 3 (tiga) Juta rupiah

Hasil penelitian adalah Cukup Baik, Saran dalam penelitian ini adalah Untuk menciptakan dan memberikan pandangan kepada responden yang merupakan kader-kader muda dalam berusaha untuk menjalankan bisnis wirausaha yang diinginkan mengingat ketatnya persaingan dunia kerja sehingga berwirausaha merupakan salah satunya jalan yang harus ditempuh.dan Kepada semua pihak agar dapat bekerja sama membentuk kader wirausaha yang handal di lingkungan Universitas Lancang Kuning Pekanbaru.
\end{abstract}

Kata Kunci : Wirausaha, Unilak, Mahasiswa

This research was held with a period of study of 3 (three) months. Where the population and the sample amounted to 42 people consisting of morning class students of semester VII Fia Unilak. The sampling technique are using census. Type of data that collected in this study includes data, past experiences, beliefs, and experiences of others. the theoretical concepts using the concept of Vincent Gaspers. Analysis of the data in this study is using qualitative descriptive analysis. The research was funded by the Faculty of Administration with funds in the amount of three (3) million rupiah.

The results of research is Pretty Good with responses as many as 18 respondents or $41.67 \%$ that responded Pretty Good which is the most dominant indicator of past experience as much as 19 respondents or 42 responses, 52\%. Suggestions in this research is to create and provide views of the respondents who are young cadres in trying to run a business entrepreneur which must to remember the intense competition in the world of work so that entrepreneurship is the one of ways to go. And to all parties to work together to form a cadre of entrepreneurs who are reliable in the Lancang Kuning University Pekanbaru

Keywords:enterpreneurs,Unilak,Study

\section{PENDAHULUAN}

Persepsi adalah pemahaman dasar yang dialami oleh individu, di mana pemahaman tersebut didapatkan dari proses penginderaan terhadap lingkungan sekitar dan individu tersebut menyimpulkan hasil penginderaannya. Sementara sikap merupakan sebuah perilaku yang dilakukan oleh individu terhadap objek sikap yang didorong oleh emosi karena terpengaruh oleh kondisi lingkungan. Sikap akan banyak terpengaruh dengan berbagai objek sikap (perilaku, dan situasi).Oleh karena itu, persepsi atau pandangan awal mahasiswa juga berpengaruh terhadap sikap mahasiswa dalam mengikuti matakuliah kewirausahaan. Diharapkan persepsi yang baik atau tinggi yang akan muncul dari mahasiswa terhadap matakuliah kewirausahaan akan membuat mahasiswa bersikap baik dalam mengikuti mata kuliah tersebut. 
Universitas Lancang Kuning Pekanbaru saat ini juga sudah menerapkan/memasukkan mata kuliah kewirausahaan pada setiap fakultasnya. Dari 9 fakultas yang ada di universitas lancang kuning semua sudah memasukkan mata kuliah kewirausahaan sebagai mata kuliah pokok yang wajib ditempuh oleh mahasiswanya. Pendidikan kewirausahaan di harapkan bisa meningkatkan kemampuan kreatif fan inovatif yang dijadikan dasar, kiat dan sumber daya untuk mencari peluang menuju sukses. Inti dari kewirausahaan yang diajarkan adalah kemampuan untuk menciptakan sesuatu yang berbeda, baru melalui berfikir kreatif dan bertindak inovatif untuk menciptakan peluang.

Persepsi Mahasiswa di Universitas Lancang Kuning Kota Pekanbaru selama ini menunjukkan bahwa ada beberapa keinginan mereka menyambut baik dengan adanya mata kuliah kewirausahaan ini, namun yang jadi masalah adalah bahwa yang mereka dapatkan hanyalah sekedar teori pembelajaran sehingga untuk terjun langsung menjadi seorang wirausaha masih sangat menakutkan bagi mereka, kurangnya pengalaman dan biaya dalam berwirausaha menjadi faktor utama mereka.

Dari hasil prasurvey yang penulis lakukan, fenomena yang terjadi rata-rata mahasiswa setelah mendapat mata kuliah kewirausahaan belum berminat untuk berwirausaha masih takut untuk terjun langsung berwirausaha karena faktor ketiadaan pengalaman dan dana dalam berwirausaha.selain itu, Sarana dan prasarana untuk berproses menjadi seorang wirausahawan yang kurang memadai . seperti koperasi sebagai contoh kecil yang belum tersedia disetiap fakultas di Universitas Lancang Kuning.bahkan ada beberapa fakultas yang belum mengadakan. Oleh karena itu, perlu adanya suatu penelitian yang menunjukkan tanggapan mahasiswa terhadap mata kuliah kewirausahaan tersebut. Sehingga dapat dirumuskan masalah penelitian ini sebagai berikut : Faktor fkctor yang mempengaruhi Persepsi Mahasiswa Tentang Mata Kuliah Kewirausahaan Di Fakultas Ilmu Administrasi Universitas Lancang Kuning Pekanbaru.

Fenomena yang terjadi adalah mata kuliah kewirausahaan mendapat tanggapan bagus dari kalangan mahasiswa, namun yang jadi masalah adalah bahwa mata kuliah tersebut hanyalah sebatas teori tanpa adanya prakterk berwirausaha sehingga menyebabkan mahasiswa kurang berani untuk terjun langsung berwirausaha karena faktor kurangnya kemampuan dan pengalaman dalam berwirausaha.

Berdasarkan uraian diatas, maka perumusan masalah yaitu : Apa saja factor factor yang mempengaruhi Persepsi Mahasiswa Tentang Mata Kuliah Kewirausahaan Di Fakultas Ilmu Administrasi Universitas Lancang Kuning Kota Pekanbaru.?

Karakteristik kewirausahaan Menurut Maredith Dalam Suryana ( 2003 : 12 ) dengan ciri-ciri dan watak kewirausahan seperti berikut :

1. Percaya Diri

2. Berorientasi kepada tugas dan hasil

3. Pengambilan resiko dan suka tantangan

4. Kepemimpinan

5. Keorisinilan

6. Berorientasi ke masa depan

Persepsi adalah proses menganalisis, mengoorganisasi dan menginterpretasikan informasi yang diterima menjadi suatu gambaran yang berarti. Menurut Philip Holter dalam buku Managemen Pemasaran (1993 : 219 ) persepsi adalah proses bagaimana seseorang menyeleksi, mengatur dan menginterpretasikan masukan-masukan informasi untuk menciptakan gambaran keseluruhan yang berarti.

Faktor - faktor yang mempengaruhi persepsi menurut Vincent dalam buku managemen bisnis( 1997 : 35 ) adalah

- Pengalaman

- Keyakinan

- Pengalaman orang lain. 
Menurut Kamus Besar Bahasa Indonesia (KBBI) persepsi adalah tanggapan/penerimaan langsung dari sesuatu proses seseorang mengetahui beberapa hal melalui panca inderanya.

Tujuan penelitian ini mencakup:

1. Tujuan Umum

-Untuk Mengetahui Dan Menganalis Persepsi Mahasiswa Tentang Mata Kuliah Kewirausahaan Di Universitas Lancang Kuning Kota Pekanbaru

-Untuk Mengetahui Dan Menganalisis Hambatan Persepsi Mahasiswa Tentang Mata Kuliah Kewirausahaan Di Universitas Lancang Kuning Kota Pekanbaru

2. Tujuan Khusus

-Untuk Mengetahui apa saja yang menjadi kendala - kendala mahasiswa di unversitas lancang kuning untuk berwirausaha.

Manfaat Penelitian :

1. Manfaat umum, bagi peneliti lain yang ingin mengkaji permasalahan kurikulum mata kuliah kewirausahaan

2. Manfaat khusus, bagi penulis lain yang ingin mengkaji Persepsi Mahasiswa Tentang Mata Kuliah Kewirausahaan .

\section{METODE}

\section{Lokasi Penelitian}

Penelitian di laksanakan di Lingkungan Fakultas Ilmu Administrasi Universitas Lancang Kuning Pekanbaru.

\section{Populasi dan Sampel}

Populasi dalam penelitian ini adalah mahasiswa semester VII kelas pagi di lingkungan FIA unilak menggunakan teknik simpel random sampling. Sedangkan Dekan dan dosen pengampu mata kuliah Kewirausahaan dijadikan key informan Untuk lebih jelasnya dapat dilihat pada table dibawah ini :

Tabel.1. Keadaan Populasi dan Sampel Penelitian

\begin{tabular}{|c|c|c|c|c|}
\hline No. & Sub Populasi & Populasi & Responden & Prosentase \\
\hline 1 & $\begin{array}{c}\text { Mahasiswa Semester } \\
\text { VII kelas pagi }\end{array}$ & 42 & 42 & 100 \\
\hline & Jumlah & & 42 & 100 \\
\hline
\end{tabular}

\section{Sumber Data : FIA Unilak Tahun 2015}

\section{Jenis Data Penelitian}

Penelitian ini menggunakan data primer yang diambil langsung dari responden yang meliputi data :

a. Persepsi Mahasiswa Tentang Mata Kuliah Kewirausahaan Di Universitas Lancang Kuning Kota Pekanbaru yaitu :

-Pengalaman masa lalu

-Keyakinan

-Pengalaman orang lain

\section{Teknik Pengumpulan Data}

Dilakukan dengan menggunakan metode Observasi,wawancara dan kuisioner.

\section{Analisis Data}

Dilakukan dengan dengan metode Deskriptif Kuantitatif 


\section{HASIL DAN PEMBAHASAN}

Hasil penelitian yakni pada tabel IV.6 dibawah ini.

Tabel 2 . Rekapitulasi Persepsi Mahasiswa Tentan Mata Kuliah Kewirausahaan

\begin{tabular}{|c|c|c|c|c|c|}
\hline \multirow{2}{*}{ No } & \multirow{2}{*}{ Indikator } & \multicolumn{3}{|c|}{ Tanggapan Responden } & \multirow{2}{*}{ Jumlah } \\
\cline { 3 - 5 } & & $\begin{array}{c}\text { Tidak } \\
\text { Baik }\end{array}$ & $\begin{array}{c}\text { Kurang } \\
\text { Baik }\end{array}$ & $\begin{array}{c}\text { Cukup } \\
\text { Baik }\end{array}$ & \\
\hline 1 & $\begin{array}{c}\text { Pengalaman } \\
\text { Masa Lalu }\end{array}$ & $\begin{array}{c}10 \\
(23,80)\end{array}$ & $\begin{array}{c}13 \\
(30,95)\end{array}$ & $\begin{array}{c}19 \\
(45,25)\end{array}$ & $\begin{array}{c}42 \\
(100.00)\end{array}$ \\
\hline 2 & Keyakinan & $\begin{array}{c}12 \\
(28,57)\end{array}$ & $\begin{array}{c}16 \\
(38,10)\end{array}$ & $\begin{array}{c}14 \\
(33,33)\end{array}$ & $\begin{array}{c}42 \\
(100.00)\end{array}$ \\
\hline 3 & Pengalaman & 10 & 12 & 20 & 42 \\
& Orang Lain & $(23,80)$ & $(28,57)$ & $(47,63)$ & $(100.00)$ \\
\hline & Jumlah & 32 & 41 & 53 & 126 \\
\hline & Rata-rata & 10 & 14 & 18 & 42 \\
\hline & Persentase & $(23,80)$ & $(33,33)$ & $(41,67)$ & $(100.00)$ \\
\hline
\end{tabular}

Sumber Data: Data Olahan Tahun 2015

Dari tabel rekapitulasi diatas dapat kita ketahui bahwa sebanyak 18 responden atau 41,67\% memberikan tanggapan Cukup Baik dimana indikator yang paling dominan adalah pengalaman masa lalu sebanyak tanggapan 19 responden atau 42,52 \%.. hal ini dengan alasan responden mereka siap untuk berwirausaha mengingat mereka sudah mendapatkan kegiatan kewirausahaan dilingkungan keluarga mereka sehingga tinggal melanjutkan saja.

Selanjutnya sebanyak 14 responden atau 33,33\% menyatakan Kurang Baik dengan indikator yang paling dominan yakni indikator keyakinan sebanyak 16 responden atau 38,10 \% . dengan alasan responden tidak memiliki keinginan dan keyakinan yang kuat dalam berwirausaha karena takut gagal dan tidak memiliki modal sehingga takut untuk berwirausaha.

Selanjutnya sebanyak 10 responden atau 23,80 persen menyatakan Tidak Baik dengan indikator yang dipilh dominan yakni indikator keyakinan sebanyak 12 responden atau 28,57 \% dengan alasan responden sama sekali tidak minat untuk menjadi wirausaha karena mereka cenderung untuk bekerja dan menjadi pegawai.

Penelitian tentang Persepsi Mahasiswa Tentang Mata Kuliah Kewirausahaan Di Fakultas Ilmu Administrasi Universitas Lancang Kuning Pekanbaru dengan responden sebanyak 42 orang yang terdiri dari mahasiswa semester 7. dengan pengambilan data yang digunakan adalah teknik sensus dan simple random sampling. Bahwa persepsi kewirausahaan mengacu pada konsep Vincet tahun 1997 bahwa persepsi dapat dilakukan dengan cara: pengalaman masa lalu, keyakinan dan pengalaman orang lain yang menyangkut motivasi-motivasi dalam berwirausaha.

Bahwa Dalam persepsi berwirausaha menurut responden dipengaruhi oleh pengalaman dan keyakinan dalam menjalankan usaha tersebut. Walaupun demikian responden masih tetap saja enggan untuk memulai kegiatan berwirausaha karena menilai kurangnya pengalaman dan modal kerja yang akan menimbulkan hutang piutang. Namun demikian juga ada sebagian yang siap untuk mencoba berwirausaha dengan menghadapi segala kemungkinan yang ada. 


\section{KESIMPULAN}

Dari hasil penelitian dan dapat disimpulkan : Hasil penelitian tentang Persepsi Mahasiswa Tentang Mata Kuliah Kewirausahaan Di Fakultas Ilmu Administrasi Universitas Lancang Kuning Pekanbaru adalah Cukup Baik dengan tanggapan sebanyak 18 responden atau 41,67\% memberikan tanggapan Cukup Baik dimana indikator yang paling dominan adalah pengalaman masa lalu sebanyak tanggapan 19 responden atau $42,52 \%$.

\section{SARAN}

a. Untuk menciptakan dan memberikan pandangan kepada responden yang merupakan kader-kader muda dalam berusaha untuk menjalankan bisnis wirausaha yang diinginkan mengingat ketatnya persaingan dunia kerja sehingga berwirausaha merupakan salah satunya jalan yang harus ditempuh.

b. Kepada semua pihak agar dapat bekerja sama membentuk kader wirausaha yang handal di lingkungan Universitas Lancang Kuning Pekanbaru

\section{DAFTAR PUSTAKA}

[1]. Anggara Sahya, 2012, Ilmu Administrasi Negara, Pustaka Setia, Bandung. .

[2]. Daryanto.2013. Pengantar ilmu manajemen dan komunikasi.ISBN.Jakarta

[3]. Gaspers, Vincet . Management Bisnis Total Dalam Era Globalisasi. Jakarta Penerbit Gramedia, 1997

[4]. Hotler, Philip Marketing Management Analyst, Prantice Hall, 1995

[5]. Hasibuan S.P, Melayu, 2010, Organisasi dan Motivasi, Bumi Aksara, Jakarta

[6]. Handoko Hani, 2009, Manajemen personalia, Penerbit Liberty, Yogyakarta

[7]. Moekijat, 2009, Manajemen Kepegawaian, Bandung, PT. Gunung Agung

[8]. Manullang,M,2009, Dasar-Dasar manajemen,Yogyakarta,UGM Press

[9]. Notoadmodjo, Soekidjo, 2009, pengembangan Sumber Daya manusia, PT Rineka Cipta

[10]. Pasolong Harbani, 2010, Teori Administrasi Publik, Alfabeta, Bandung.

[11]. Padmuji, 2009, Administrasi Kantor Manajemen dan Aplikasi, Jakarta. Penerbit, Djambatan

[12]. Saputra, T. (2016). Pengaruh Motivasi Kerja Terhadap Disiplin Kerja Pegawai Pada Dinas Pemuda Dan Olahraga Provinsi Riau. Jurnal Niara, 8(2), 50-60.

[13]. Siagian P Sondang, 2011, Filsafat Administrasi, Jakarta Hajimasagung 
[13]. Syafiie,Inu Kencana, 2011, Sistem Administrasi Negara, Bumi Aksara, Jakarta.

[14]. Siagian P. Sondang, 2011, Filsafat Administrasi, Bumi Aksara, Jakarta.

[15]. Sofiyan Efendi,masri Singarimbun Metode Penelitian Survei, LP3ES, 2009, Jakarta

[16]. Suryana . 2003 . Kewirausahaan . Penerbit Salemba Empat. Jakarta 